\title{
Knowledge and Technology Transfer in the Age of Enlightenment: The Scientific Correspondence between Franciszek Bieliński (1683-1766) and Henri Louis Duhamel du Monceau (1700-1782)
}

\author{
Małgorzata Durbas \\ Jan Dlugosz University in Częstochowa \\ ul. Waszyngtona $4 / 8$ \\ Częstochowa 42-200, Poland \\ Email:m.durbas@ajd.czest.pl
}

Abstract: The scientific life in mid-seventeenth-century Europe was characterised by numerous academies of sciences and scientific associations whose aim was to propagate the development of the sciences, art and literature. Some have called it "the new Age of Academies all over Europe". These institutions brought together not only educated professionals but also a large number of amateur scientists. They called for the deliberate abandonment of verbal dispute in favour of visual demonstration/experimentation, and for the creation of paid scientific professionals who would devote their full time to the enterprise. These scientists conducted numerous experiments, the results of which were demonstrated at academic sessions.

Franciszek Bieliński became Grand Marshal of the Crown in 1742. During the many years of his public service, he aimed to improve the well-being of Warsaw inhabitants, especially by paving the streets and creating a modern sewerage system. In the light of recent scholarly studies, Franciszek Bieliński is perceived as a figure of very wide horizons, striving to join the Parisian academic scientific discourse in order to transfer knowledge and technology to Poland. Bieliński exchanged letters with the eminent member and three-time president of the Paris Academy of Sciences (1666-1803), Henri Louis Duhamel du Monceau, who among numerous other projects tested new methods of horticulture, agriculture and forestry.

The article aims to discuss the scientific research undertaken by Bieliński in regards to technology transfer in the area of agriculture, on the basis of unanalysed documents. Recently found correspondence shows that Grand 
Marshal Bieliński was involved in experimental research supervised by Duhamel du Monceau, under the aegis of the Paris Academy of Sciences. It pertained to modern agricultural crops and the application of new technologies. The agricultural experiments that Bieliński carried out on his private lands in Otwock over many years focused on improving and increasing agricultural production in accordance with the instructions given by Duhamel du Monceau. An interesting research finding was the detailed description of one of the earliest transfers of advanced technology in the field of agricultural machinery. Reports of the work conducted in Poland, which were sent to Duhamel du Monceau, proved to be so useful and important that the latter mentioned these in the proceedings of the Paris Academy of Sciences.

Keywords: agriculture, Henri Louis Duhamel de Monceau, Marshal Franciszek Bieliński, Paris Academy of Sciences, public works in Warsaw, technology transfer

The development of science in the modern era was greatly boosted by numerous academies of sciences and scientific associations established at that time. They were public institutions, acting for the benefit of the state in the areas of education, defence or economy, and aimed to encourage cooperation among scientists, to transfer knowledge and establish costly workshops, especially experimental laboratories. Obtaining membership in one of such organisations was the object of endeavours, complicated manoeuvres and, as a result, a source of personal satisfaction and social prestige (Hahn, 1971; Roche, 1978; 1974). Merging into this scientific environment was almost impossible for a Polish magnate. It was much easier to initiate correspondence cooperation, consisting in the exchange of observations in the form of letters, regarding research areas that were highly appreciated by scientists. This fact suggests that academics created their own world, a world requiring personal and social recognition and appreciation, so they strived to make the world around them a better place, covering more and more space in their research areas. This overwhelming scientific curiosity reigning in the European minds of the Age of Enlightenment attracted the attention of many passionate individuals, who were fascinated with and hungry for knowledge. Their non-explicit aim was to contribute to that timeless, empirical academic discourse. Once published, materials from academic research reached many environments and countries. They were accessible even in the circles of the Polish aristocracy and nobility, thus spreading knowledge about scientific research issues, provoking interest and encouraging further practices. One of very 
few men of very broad horizons who nota bene desired to actively contribute to the research initiated in the Paris scientific environment was Marshal Franciszek Bieliński (Waniczkówna, 1936, pp. 475-476; Fig. 1).

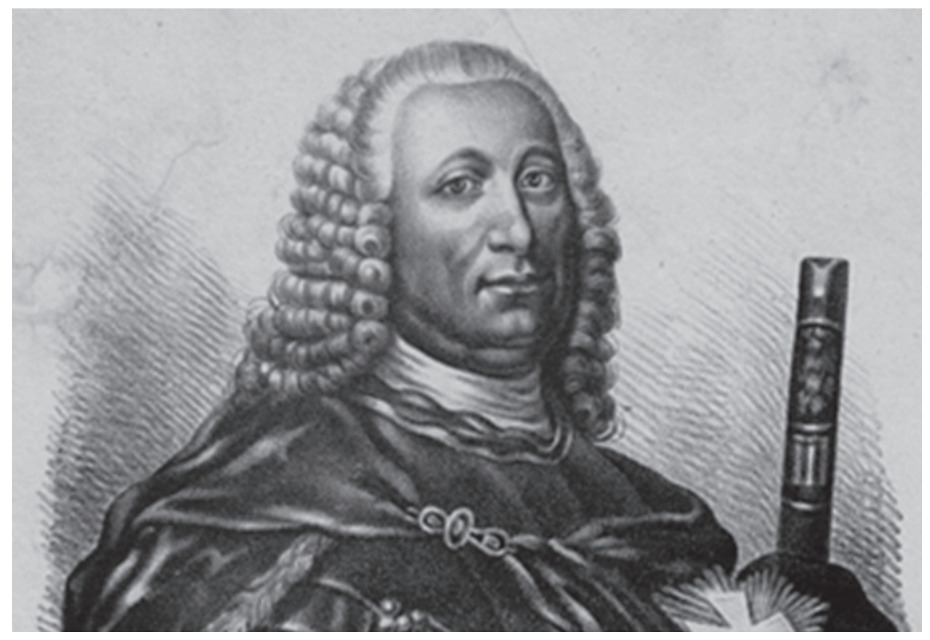

Figure 1. Portrait of Franciszek Bieliński by Franciszek Kostecki (IPSB, n.d.)

During my research conducted in connection with a book about the Académie de Stanislas Leszczynski in France, I came across a Polish sounding surname marechal Bielinski in one of the books. Further familiarisation with the book's contents revealed that Grand Marshal of the Crown Franciszek Bieliński corresponded with the French academic Duhamel du Monceau. The discovered correspondence constitutes a very precious source from the perspective of research concerning the history of knowledge and technology transfer in the middle of the 18th century. It is a living testimony of innovations in the area of agriculture introduced in Poland at that time, and it is an introduction to further source research, which is the aim of this article.

In Polish historiography, apart from his strictly political activity, Marshal Franciszek Bieliński (Waniczkówna, 1936, p. 475) is above all remembered as a man caring about order in Warsaw and strictly executing his judicial powers to fight crime. Once he was appointed Grand Marshal of the Crown in 1742 and took over the presidency of the Cobblestone Commission established a bit earlier, Franciszek Bieliński initiated a series of actions aiming at introducing several novelties in Warsaw (Baranowski, 1919, pp. 5-24). It was at that time when all real estate units in the city were measured to make the capital a more ordered place and to define the elbow tax to cover the costs connected with 
covering the capital's streets with cobblestone. As a man consistently striving to achieve his goals, well-educated and open-minded, Bieliński spared no effort to introduce visual law and order in the Polish capital. Thanks to his efforts, the city of Warsaw obtained financial help from the state (Baranowski, 1919, p. 11) and sometimes he personally financed certain projects. Even King August III tried to support these new initiatives financially. These efforts translated into many kilometres of cobblestones in the city. The Marshal strived to obtain the royal privilege (1761) to organise a "lottery", the proceeds of which were intended to cover the costs of works commissioned by the Cobblestone Commission. A memento of those measurements to cobblestone the capital is a beautifully printed map of Warsaw, commissioned by the Marshal and preserved until today (Kowalczyk, 1988-1989, pp. 303-304). Bieliński did not content himself with paving the capital. He wanted to introduce cleanliness into its streets, which was a truly innovative undertaking at those times. To achieve this, he established the so-called "captive fleet" also known as a "cart warehouse" whose task was to systematically clean city streets (Walendowski, 2008, pp. 36-42).

He issued harsh resolutions addressed to the inhabitants, forcing them to keep the city clean, and a resolution to protect the city from fires. Bieliński also directed may of his endeavours to the issue of erecting more brick houses in the capital. Thanks to his efforts, in 1764, the Diet prohibited the renovation of wooden houses and ordered to knock down the ones endangering the safety of neighbouring houses. To facilitate the construction of brick houses, he introduced a "fee for bricklayers, carpenters, sawyers and pavers" that had to be strictly kept (Waniczkówna, 1936, p. 49). Franciszek Bieliński enjoyed great respect and was appreciated by the Warsaw community for his many years of fruitful public service aiming at improving its living conditions. He was also adamant about introducing law and order in the city. Already four years after his death, a street in the city was called Marszatkowska to commemorate the Marshal, and it still bears the same name. It should be added here that the biography of Bieliński, as one of very few Marshals of the Crown of the 18th century, was mentioned in the first edition of the great French bibliography by Michaud (1843, p. 292).

Franciszek Bieliński was a prosperous landowner. He used to call himself "Earl of Radzymin, Bielin, Otwock, Karczewo and Parysowo" (Waniczkówna, 1936, p. 48). In his childhood, he lived with his parents and siblings in Warsaw in a palace built by his grandfather, Jan Andrzej Morsztyn. After the death of his father Kazimierz Ludwik Bieliński in 1713, Franciszek inherited the land of Otwock Wielki (Baranowska, 1988, pp. 263-264), an estate in Miętno which he often 
frequented, but he chose Warsaw as his main residence (Putkowska, 1996, p. 18). He built a palace on a plot of land purchased by his father, on Królewska Street. On the outskirts, it was completed by a wooden manor house on the isle of Solec (Waszkiewicz, 1972, pp. 79-147). Marshal Bieliński moved to the estate of Otwock Wielki (Baranowska, 1988, p. 264) in about 1735 and made it the main residence, introducing many changes. Since that time, it was a formal, official residence where he used to host even foreign diplomats, including the French (Waniczkówna, 1936, p. 48). The period of over 30-year governance of Otwock by Franciszek Bieliński was characterised by numerous investment works, conducted in at least two stages. Palace modernisation consisted mainly in adjusting its interior to a new way of its usage, i.e., the whole-year stay (Putkowska, 1996, p. 33). That period witnessed the construction of a magnificent park complex, west of the isle, and a large manor with a granary, brewery house and stables on the northern side of the lake. These two developments, designed symmetrically, were joined by a compositional axis with the centrally-located palace, which gained an additional function, becoming a centre administering the modern farm (Baranowska, 1988, pp. 264; 267). The building itself did not undergo many alterations. Tastes, including artistic ones, shaped under the influence of French culture, which Franciszek certainly absorbed in his family home, had a great impact on the palaces, furnishings and their further modernisation. The Marshal's grandmother on his father's side was Anna Akierstoff, Marie Louise's lady-in-waiting (Baranowska, 1988, pp. 264; 267). Probably around 1700 he did the Grand Tour during which he stayed in Paris. It is known that he studied at the Paris Academy of Nobles François Longpré and Jean Bernardy (Wyszomirska, 2000, p. 110)

In the middle of the eighteenth century, Marshal Franciszek Bieliński initiated epistolary contact with a Paris academic, Henri-Louis Duhamel du Monceau (Michaud, 1843, p. 468; Fig. 2).

Duhamel du Monceau (Corvol, 2001; Dupont de Dinechin, 1999) was an exceptional representative of the Age of Reason. Condorcet said that he was the best-educated man in Europe in every branch of science (de Pelet, 1986, p. 236). He was a lawyer by profession but showed a passionate interest in versatile research subjects. Duhamel du Monceau had an exceptional personality of a scientistexperimenter as he based his scholarly activity on personal observation of facts complete with experiments. Early research discoveries regarding the eradication of diseases in the cultivation of saffron placed young Duhamel du Monceau not only in the position of the founder of plant pathology but made it possible for him to occupy a position of a substitute for an academic-botanic in the Paris 


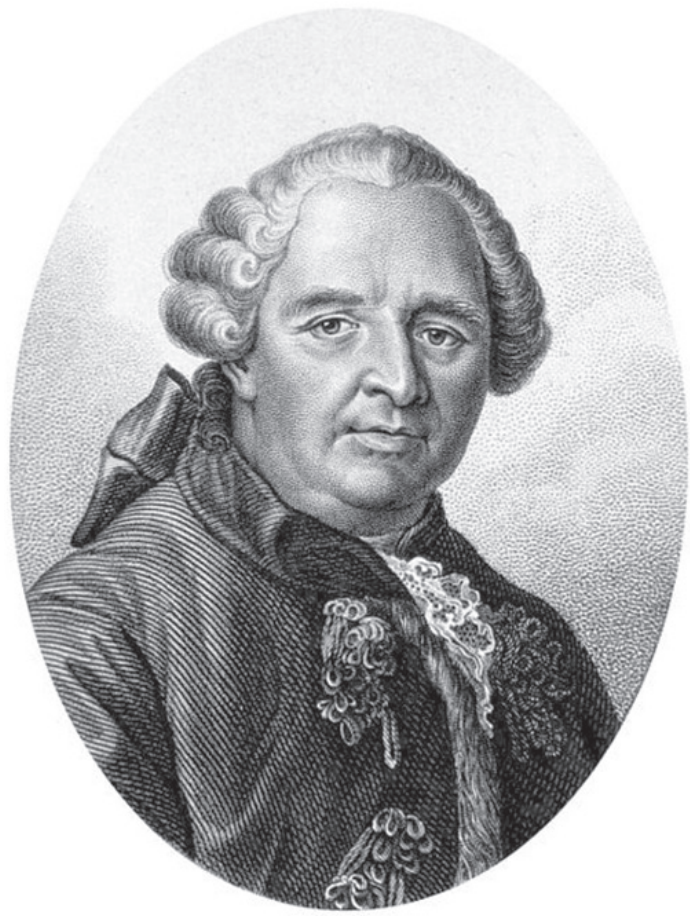

Figure 2. Henri Louis Duhamel du Monceau, Engraving by François-Hubert Drouais (US National Library of Medicine Digital Collections, n.d.)

Académie royale des sciences in 1728 . He conducted research in the then widely understood nature sciences. He also analysed the relations between rainfall, plant growth and temperature. Furthermore, he was occupied with meteorology, chemistry and, together with Bernard de Jussieu, horticulture. Since the 1730s, he was involved in wood processing for the shipbuilding industry, and over time, he became recognised as an expert in that field (Villiers, 2006, pp. 2340). Additionally, Duhamel du Monceau left his mark in political circles where he was supported by Count Maurepas (Jean Frédéric Phélypeaux, Comte de Maurepas), as emphasised by researcher Patrick Villiers (2012, pp. 505-515). By the resolution of King Louis XV of 1739, he was appointed Inspector-General of the Marine, and he served in that function until the end of his life. Three times he was appointed vice president of the French Academy of Sciences (in 1742, 1755 and 1767) and its president (in 1743, 1756 and 1768). After René Antoine Ferchault de Réaumur's death, Duhamel took over the publication of the Descriptions des Arts et Métiers for the benefit of the Royal Academy. 
Only since 1748, after his translation of an English work by Jethro Tull (Donald, 1908, pp. 186-190), did Duhamel du Monceau concentrate his experimental research on agriculture and agronomy. The Academy made him responsible for supervising this branch of economy. It was at that time that he initiated the publication of a series of works, Treatise on Land Cultivation (Traite de la culture des terres) (Duhamel du Monceau, 1753-1761), under the auspices of the Academy. These texts concerned grain cultivation, ways of ploughing, sowing or crop protection (Bourde, 1967, p. 257). The Parisian academic conducted his experimental research in his family estate, Denainvilliers, near Pithiviers, located north of Orléans. He was assisted by his brother Duhamel de Denainvilliers and his two nephews, one of whom continued research work and became a member of the French Academy of Sciences (de Pelet, 1986, p. 237). Beginning in the 1740s and until his death, he conducted meteorological observations in his estates together with his brother, meticulously noting in his reports such elements as temperature, insolation or rainfall, hail, etc. The results of the observations, especially those regarding the cultivation of cereals or meteorology, were scrupulously included in the minutes from the sittings of the French Academy of Sciences and sometimes published in Bulletin de l'Académie des sciences (Desarthe, 2010, p. 74)

Duhamel du Monceau was the best agronomist on the European continent (Chaunu, 1989, pp. 266-267). His desire to make science useful won him almost everybody's respect. He adored practical tasks and took several measures to quickly comprehend and absorb all technical innovations (Bourde, 1967, p. 257). Among the numerous discoveries devoted to scientific research, one, seemingly insignificant, was of great importance to nations as it regarded the way of preserving and storing crops (Chaunu, 1989, p. 266). During fifty years of active academic life, Duhamel du Monceau published nearly 60 articles in Mémoires de l'Académie royale des Sciences. He wrote about 20 monographs in the descriptions from the published collection of arts and crafts Descriptions des Arts et Métiers, which constituted a source of reference for encyclopaedists who compiled the Encyclopédie. What is more, this erudite described crucial scientific issues of his time in 15 books (treatises), discussing, for example, ship construction, fish and fishing history, or maintaining health on ships.

Moreover, accompanied by a group of academics, du Monceau issued many expert opinions commissioned by the Royal Academy.

The multitude of research undertaken by Duhamel du Monceau made him seek help among people hungry for knowledge and those ready to face diligent and 
systematic work. The issue of correspondents of the said scientific institution was formally solved by the Academy's resolution of 1753, describing conditions of admittance and the responsibilities of permanent correspondents (Desarthe, 2010, p. 78). However, there were exceptions to those regulations caused by social interest in some areas of knowledge. The series of articles published by Duhamel, Traité de la culture des terres, containing descriptions of technical novelties concerning the improvement of agricultural tools, ways of soil preparation or fertilisation, sowing, climatic conditions and other circumstances influencing agricultural production, evoked a substantial social interest. In the preface to the fifth volume of Traité de la culture des terres (Duhamel du Monceau, 1757, pp. 5-32), Duhamel reported on a great number of correspondents interested in science development, who kept sending descriptions of experiments conducted in their estates with the help of all the innovations:

We are truly glad every time the number of our engaged correspondents grows. It is their work and research that we present to our readers in the fifth volume of the publication concerning land cultivation that we are releasing ${ }^{1}$.

It is worth mentioning that, apart from the territory of France, these experiments were also conducted in Great Britain, Switzerland, and even on Bourbon Island (nowadays Réunion) which belonged to the monarchy at that time. Even King Stanisław I Leszczyński engaged in these experiments, encouraging his academics from Nancy to continue the agricultural research. One of those scholars, Credo (François), sent to Paris an already printed version of reports on that subject (Durbas, 2017, pp. 70-80). During his whole career, Duhamel had 24 permanent correspondents, not only from the area of Paris and France, but also from abroad. He also partially took over some correspondents of his colleague, Réaumur, who died in 1757 (Desarthe, 2010, p. 78).

Having analysed all the works from the series Traité de la culture des terres, it may be concluded that the only Pole who undertook academic exchange of thoughts and kept introducing agricultural innovations on the territory of his estates in Poland, in his estate in Otwock, was Grand Marshal of the Crown Franciszek Bieliński.

It is not known to me how Bieliński came into contact with Duhamel. It is known that, as an enthusiast of all innovations, the Marshal was open to

\footnotetext{
"Nous avons encore la satisfaction de voir multiplier le nombre et le zele de nos Correspondants. Ce sont leurs travaux, leurs recherches, que nous presentons au public dans ce cinquieme volume sur la culture des terres, que nous mettons au jour" (Duhamel du Monceau, 1757, p. 5). The original French spelling of the time has been retained.
} 
changes. While writing about the estate in Otwock, researcher Zofia Baranowska emphasises that the Palace in Old Otwock was a centre for "managing a modern farm" (Baranowska, 1988, pp. 264; 267). In the 30s, Bieliński ordered the interior design of drawing rooms for the palaces in Warsaw from a French architect and sculptor, Juste-Aurèle Meissonnier (Putkowska, 1996, p. 28). It is also known that in February 1747, the Grand Marshal of the Crown went to France on a political mission (Waniczkówna, 1936, p. 49), where he might have got interested in the Academy's publications or might have met some academics in person. After this stay he wrote a few letters to Academic René Antoine Ferchault de Réaumur, describing bird behaviour and clearly stating that he had made all observations in his estate in Otwock. The remarks included in the correspondence went hand in hand with ornithological observations conducted in Paris by the great academic (Daszkiewicz, 2008, pp. 211-218; 2009, pp. 85-87). The Marshal could have got familiar with other fashionable research trends.

The first letter of Marshal Bieliński was reprinted in the fifth volume of a treatise on land cultivation in 1757 (Duhamel du Monceau, 1757, pp. 118-125). The Pole reported his experiences and remarks on agricultural production and grain conservation in the years 1755 and 1756 . In the preface to the reprinted reports, the Parisian academic Duhamel informed the readers that the Pole imported new models of ploughs, seeders and even granaries from Paris, and that:

This Lord [Bieliński-M. D.] currently he could share with me [Duhamel-M. D.] the success of his first attempts. It is so noble when one chooses useful things as objects of their amusement! This way, they become more interesting to ourselves and we can feel real satisfaction when we see how beneficial they become to society. ${ }^{2}$

Indeed, in his report sent to Paris, Bielinnski informed the academic that thanks to the new machinery he had begun a series of experiments. He wrote that they had been conducted in climatic conditions different from the French ones and that despite difficulties from the workers' and farmers' side, the experiments let him achieve some success and persuade others to implement new methods on a broader scale. In his estate, near the palace, the Marshal selected a part of a

2 "Ce Seigneur est déja en état de me faire part des succès de ses premiers tentatives. Qu'il est beau de choisir pour objet de son amusement des choses veritablement utiles! On les rend ainsi plus intéressantes pour soi et on a une vrai satisfaction de les voir tourner à l'avantage du public." (Duhamel du Monceau, 1757, p. 119) 
large field with quite good soil, often fertilised with natural manure, and ordered to plough it with an ordinary plough and set patches. As he described-the previous year-the field had been sown with wheat, then ploughed twice and sown again, this time with Mr Montesui's seeder (Duhamel du Monceau, 1761, p. 272). Bieliński gave very precise information about the works in question; how much grain was used with the new method and how much had to be used with the old one. Describing all his activities daily, he shared the most detailed remarks with the Parisian academic such as the surface of experimental fields, temperature, rainfall, the extent to which crops were scarified or even how many sprouts he spotted on the plants.

[B] arley has become very beautiful and has grown significantly: all stalks which I inspected on quite a wide patch and they had 12 to 20 sprouts and the width and dark-green shade of leaves let them be easily distinguished from barley sown on the rest of the field in a traditional way. ${ }^{3}$

He lists scrupulously draught days and continuous rain, which, to a certain extent, impeded the growth and prevented him from obtaining good harvest. He additionally noted that had he sown his fields earlier, the harvest could have been more efficient. He would have avoided draught then. The report in the form of a letter finishes with a description of recent works conducted on the experimental fields before the approaching winter.

The next letter (Duhamel du Monceau, 1761, pp. 62-65) was reprinted in the sixth volume of the treatise. Bielinski writes there that ploughing with the help of a light plough and cultivator went smoothly and the field sown with wheat rendered the harvest of 1,660 semi-quarts of pure grain. The Marshal compared these results with the last year's ones. "Sowed the same field with more fertile barley and obtained greater yields."

However, to facilitate cultivation and sowing, Marshal Bieliński ordered to select a triangular piece of the field sown with barley of the surface of 100 square perches $[3418 \mathrm{sq} \mathrm{m}]^{4}$ —which constituted one-sixth of the whole field, and he ordered to sow it with wheat; so the crop was diminished by this value, which lets us conclude that had it not been for these circumstances,

3 "l'orge devint très-belle et alla considérablement: tous les pieds que j’examinai dans une portion de planche assez étendue, portait depuis 12 jusqu'a 20 tiges, qui se distinguaient facilement de l'orge semée à l'ordinaire dans le reste du champ, par la largeur et le le vert foncé de leurs feuilles." (Duhamel du Monceau, 1757, p. 123)

4 Square perch (Paris) $=34.18$ square meters. 
the wheat crop would have been as big as the barley one, keeping the proportions regarding grain differences. ${ }^{5}$

Moreover, he remarks that the experimental field was remotely located, ravaged by birds, unfavourable climatic conditions and hail. The loss was estimated at $1 / 2$ of the value whereas in case of barley it was $1 / 6$.

Summarising his experiences, in his letter to Duhamel du Monceau, Bieliński listed several interesting remarks concerning the number of rows sown, the width of patches devoted to the new method cultivation, careful soil preparation, the period of cereal sowing and even protecting the grain from birds. He also informed about the kind of seeder he had used. It was a machine constructed on the basis of the description included in the work Traité de la culture des terres (Duhamel du Monceau, 1757, p. 281). However, after the first fieldwork, Marshal Bieliński suggested removing rear wheels from the seeder, considering them unnecessary. He also found it important to increase the amount of grain for sowing.

The third letter is a description of a funny experience aiming at saving the grain ravaged by grain weevil. The grain was intended for producing beer but in the period of sprouting, germs were consumed by the pest. To save the damp grain and to make it useful as fodder, Marshal Bieliński constructed a drying machine according to the sketches and technical design by Duhamel du Monceau. Already in his preface to the letter sent to Paris, he remarked that he had constructed the machine using the academic's original description. At the end of a printed version of Bieliński's report, the Parisian academic expressed his surprise that Marshal Bieliński was able to put such damp grain into the pipes.

To conclude, the letters in the form of reports from conducted experiments sent to the academic Duhamel du Monceau inform us that Franciszek Bieliński imported from Paris, in 1756 or 1755, agricultural machines such as two types of ploughs, seeders (at least two items), cultivators and even "our granaries". Benefiting from Duhamel's technical descriptions by Duhamel, the Marshal ordered to construct in Otwock a unique type of drying machine for the grain intended for beer production, which unfortunately got damp. Bearing in mind

5 "Pour faciliter les culture et les semailles, $M$. le Comte de Bielinski avoit fait retrancher du champ semé en orge, avant de l'ensemenceren froment, une portion triangulaire évaluée 100 perches quarrées, ce qui fait un sixieme du champ; la récolte a donc été diminuée de cette quantité, d'ou l'on peut inférer que, sans ces circonstances, la récolte du froment auroit été, prportion gardée relatvement à la differencedes grains, aussi bonne que celle d'orge M. le Grand-Maréchal ajoute les remarques suiantes, qui sont toutes très-interesantes." (Duhamel du Monceau, 1761, p. 63) 
the above, it should be emphasised that Bieliński was familiar with Duhamel's works and his designs concerning the construction of granaries (Waniczkówna, 1936 , p. 48). As far as crops are concerned, we have information about the experimental field located near the palace, in the vicinity of the stables. Analysing the map of the whole Otwock by Plant (Putkowska, 1996, p. 32), it can be concluded that the experimental fields were marked on the map and are located between the brewery, the main manor house and the stables. The Marshal said that a part of experimental land cultivation was also performed in more remote regions. On the other hand, we have merely two pieces of information concerning the agricultural machines and the fact that all of them were propagated by Duhamel du Monceau in his Traité de la culture des terres. The publication of the first letter on agriculture from Bieliński was preceded by four volumes of Traité de la culture des terres, numerous articles in Memoires de l'Academie des sciences, or individual texts by Duhamel dealing with grain conservation or granary construction. Bieliński was familiar with this professional literature and he personally mentions it more than once (Duhamel de Monceau, vols. I-VI). Therefore, a question arises what these machines, ploughs, cultivators and seeders looked like. The answer can be found on the pages of Traité de la culture des terres.

These works frequently mention the name of one of his contemporary correspondents, Michel Lullin de Châteauvieux (Michaud, 1820, p. 425), as the designer of a modern plough and, undoubtedly, a seeder. The entry about "the plough and seeder of Mr Châteauvieux" (de Châteauvieux, 1754, pp. 1-158) was highly innovative in public space of that time. Moreover, Lullin de Châteauvieux designed a single cultivator described a few years later by an Englishman John Mills (1767). Duhamel collected and published observations and various designs sent to him. The Polish magnate, Marshal Franciszek Bieliński joined that academic discussion concerning agriculture. According to Pierre Chaunou,

Duhamel du Monceau was a man who in the middle of the 18th century constituted a turning point in French agriculture due to the fact that slow preparation for the agricultural revolution was an issue not purely scientific or technical, but a matter of making all innovations widely known and unified. (Chaunu, 1989, p. 189)

When we talk about the transfer of knowledge, new ways of land cultivation, and production or new technologies, we should consider what conditions should be fulfilled to trigger that process. In fact, a crucial and even indispensable element of the process of knowledge transfer is sharing it. Knowledge transfer takes place between two participants or a bigger number of people, institutions or 
organisations (Van den Hooff, 2004, p. 118). In the case of Marshal Franciszek Bieliński and Duhamel du Monceau, this condition was fulfilled. Bieliński, as a recipient of information, became familiar with Duhamel's knowledge concerning agricultural production and new ways of machine construction, and he exchanged the observation results with the sender. Thus, there was a two-way process during which the individuals exchanged their knowledge, and we can talk about knowledge and technology transfer (Van den Hooff, 2004, p. 118). Scientific treatises or theses disseminated by way of academic publications and were accessible to a wider group of readers, reaching their audiences not only in the West, but also found their way to other climatic and cultural zones. "The multitude of periodicals and scientific reviews constituted the ties in the community of minds, without obligations and statutes..." (Chaunu, 1989, p. 189). They contributed to information transfer. Marshal Franciszek Bieliński was one of very few figures striving to actively contribute to the research initiated in the Parisian scientific environment, according to his capabilities. The said correspondence illustrates the transfer of knowledge and technology and constitutes an introduction to further source research.

\section{References}

Baranowska, Z. (1988), 'Pałac w Starym Otwocku (z historii budowy w XVII i przebudowy w XIX stuleciu)' [Palace in Stary Otwock (construction in the 17th and reconstruction in the 19th century)] Rocznik Historii Sztuki, vol. 17, Ossolineum.

Baranowski, I. T. (1919), Marszałek Franciszek Bieliński [Marshal Franciszek Bieliński], Warszawa: Polskie Tow. Krajoznawcze.

Bourde, A. J. (1967), Agronomie et agronomes en France au XVIII siècle, Paris: Sevpen.

Châteauvieux de, M. L. (n.d.), 'Expériences et réflexions sur la culture des terres, faites aux environs de Genève, dans les années 1754, 1755 et 1756,' in Duhamel de Monceau, H. L. (1754-1761) Traité de la culture des terres par M. Duhamel de Monceau, Paris: H. L. Guérin.

Châteauvieux de, M. L. (1754), 'Description d'un nouveau semoir inventé par M. Lullin de Châteauvieux, syndic et juge de police de la ville et de la république de Genève, avec figures en taille-douce,' in Duhamel de Monceau, H. L. (1754-1761) Traité de la culture des terres par M. Duhamel de Monceau, Paris: H. L. Guérin.

Chaunu, P. (1989), 'Cywilizacja wieku Oświecenia' [The civilisation of the Age of Enlightenment], Warszawa: Państwowy Instytut Wydawniczy. 
Knowledge and Technology Transfer in the Age of Enlightenment: The Scientific Correspondence between Franciszek Bieliński (1683-1766) and Henri Louis Duhamel du Monceau (1700-1782)

Corvol, A. (2001), 'Duhamel du Monceau, un philosophe du siècle des Lumières,' Actes du colloque du 12 mai 2000, Académie d'Orléans.

Daszkiewicz, P. (2008), 'Korespondencja Wielkiego Marszałka Koronnego Franciszka Bielińskiego (ok. 1683-1766) z francuskim uczonym René-Antoine Ferchault de Reaumur (1683-1757)—interesujący dokument historii polskiej zoologii' [Correspondence of the Grand Marshal of the Crown Franciszek Bieliński (ca. 1683-1766) with the French scientist René-Antoine Ferchault de Réaumur (1683-1757) —an interesting document of the history of Polish zoology], Przeglad Zoologiczny, LII 1-2, pp. 211-218.

Daszkiewicz, P. (2009), 'Polonika w archiwum René-Antoine Ferchault de Réaumur (1683-1756)' [Polonica in the Archives of René-Antoine Ferchault de Réaumur (1683-1756)], Kwartalnik Historii Nauki i Techniki, R.54:2009, no. 2, pp. 83-93.

Desarthe, J. (2010), 'Duhamel du Monceau, météorologue,' Revue d'histoire moderne et contemporaine, no. 57-3, pp. 70-91. https://doi.org/10.3917/rhmc.573.0070

Duhamel du Monceau, H. L. (1750-1753), Traité de la culture des terres, suivant les principes de M. Tull, anglois, vols. 1-2, Paris: H. L. Guérin.

Duhamel du Monceau, H. L. (1754), Traité de la culture des terres, vols. 3-4, Paris: H. L. Guérin.

Duhamel du Monceau, H. L. (1757), Traité de la culture des terres, vol. 5, Paris: H. L. Guérin.

Duhamel du Monceau, H. L. (1761), Traité de la culture des terres, vol. 6, Paris: H. L. Guérin.

Dupont de Dinechin, B. (1999), Duhamel du Monceau, un savant exemplaire au siècle des Lumières, Luxembourg: CME.

Durbas, M. (2017), 'Scientific research in Stanislaw Leszczynski Academy in Nancy in the field of agriculture and the use of this research in practice (1750-1766),' Acta Baltica Historiae et Philosophiae Scientiarum, vol. 5, no. 1, pp. 70-80.

Hahn, R. (1971), The Anatomy of a Scientific Institution: The Paris Academy of Sciences, 1666-1803, Berkeley, Los Angeles \& London: University of California Press.

IPSB (n.d.), 'Franciszek Bieliński - portret (autor: Franciszek Kostecki)' [Image], Internetowy Polski Stownik Biograficzny. Retrieved from https://www.ipsb.nina.gov. $\mathrm{pl} / \mathrm{a} /$ foto/franciszek-bielinski-portret-autor-franciszek-kostecki [accessed Oct 2020]

Kowalczyk, J. (1988-1989), 'Pierre Ricaud de Tirregaille 1725-1772,' Polski Stownik Biograficzny, vol. 31: Zakład Narodowy im. Ossolińskich-Polska Akademia Nauk.

McDonald, D. (1908), Agricultural Writers, from sir Walter of Henley to Arthur Young: 1200-1800, London: Horace Cox.

Michaud, L. G., ed. (1820), Biographie universelle, ancienne et moderne, ou Histoire, par ordre alphabétique, de la vie publique et privée de tous les hommes..., vol. 25, Paris: Michaud Frères. 
Michaud, L. G., ed. (1843), Biographie universelle, ancienne et moderne, ou Histoire, par ordre alphabétique, de la vie publique et privée de tous les hommes..., vols. $2 \& 11$, Paris: Michaud Frères.

Mills, J. (1767), A New System of Practical Husbandry, London: J. Johnson and B. Davenport.

Pelet, de J. (1986), 'Henri Louis Duhamel du Monceau, agronome et savant universel (1700-1782) ou un encyclopédiste au siècle de Diderot,' Culture Technique, no. 16, pp. 236-245.

Pueyo, G. (1980), 'Un initiateur de la météorologie agricole au XVIII e siècle, HenriLouis Duhamel du Monceau,' Comptes rendus des séances de l'Académie d'agriculture de France, pp. 944-952.

Putkowska, J. (1996), 'Warszawski zespół rezydencjalny Franciszka Bielińskiego marszałka wielkiego koronnego' [The Grand Marshal of the Crown Franciszek Bieliński's Warsaw residence complex], Kwartalnik Architektury i Urbanistyki, vol. 61 , no. 1 .

Roche, D. (1974), 'Sciences et pouvoir dans la France du XVIII siècle (1666-1803),' Annales, économies, sociétés, civilisations, vol. 29, no. 3.

https://doi.org/10.3406/ahess.1974.293506

Roche, D. (1978), Le siècle des Lumières en provinces: Académies et académiciens provinciaux 1680-1789, vols. 1-2, Paris-La Haye: Mouton.

US National Library of Medicine Digital Collections (n.d.), 'Hy. Ls. Duhamel Sgr. du Monceau / Peint par Drouais fils. Gravé par Ambroise Tardieu,' B07529, Engraving by François-Hubert Drouais. Retrieved from http://resource.nlm.nih. gov/101414032 [accessed Oct 2020]

Van den Hooff, B. \& De Ridder, J. A. (2004), 'Knowledge sharing in context: The influence of organizational commitment, communication climate and CMC use on knowledge sharing,' Journal of Knowledge Management, vol. 8, no. 6, pp. 117-130. https://doi.org/10.1108/13673270410567675

Villiers, P. (2006), 'Duhamel du Monceau et Maurepas, une rencontre inattendue,' Chronique d'histoire maritime, no. 61.

Villiers, P. (2012), 'De la recherche fondamentale à la recherche appliquée, le recrutement de Duhamel du Monceau dans la marine par Maurepas : un recrutement secret?' International Archive of the History of Science, numéro thématique: Les sciences à la cour de Versailles et la naissance des politiques scientifiques en Europe, vol. 62, fasc. 169. https://doi.org/10.1484/J.ARIHS.5.101914

Walendowski, H. (2008), 'Błoto dochodziło koniom po brzuchy' [Mud was reaching the bellies of the horses], Bruki warszawskie, no. 34 I 5/2008. Retrieved from www. rynekkamienia.pl [accessed Jun 2020]

Waniczkówna, H. (1936), 'Franciszek Bieliński,' in Polski Stownik Biograficzny, vol. 2, Krakow: Polska Akademia Umiejętności. 
Knowledge and Technology Transfer in the Age of Enlightenment: The Scientific Correspondence between Franciszek Bieliński (1683-1766) and Henri Louis Duhamel du Monceau (1700-1782)

Waszkiewicz, J. (1972), 'Jurydyka Bielino,' Studia Warszawskie, vol. 2: Warszawa XVIII wieku, z. 1.

Wyszomirska, M. (2020), “"Niech się nikt nie cieszy ani urąga z naszej przyjaźni.” Obraz wzajemnej więzi w listach Franciszka Bielińskiego do Elżbiety Sieniawskiej z lat 1712-1729' ['Let no one rejoice or scoff at our friendship." The mutual bond in Franciszek Bieliński’s letters to Elżbieta Sieniawska from 1712-1729] in Działalność Elżbiety Sieniawskiej. Polityka - gospodarka - kultura, ed. by Bożena Popiołek, Warszawa: Muzeum Pałacu Króla Jana III w Wilanowie.

Zielińska, T. (1977), Magnateria polska epoki saskiej [Polish magnates of the Saxon period], Wrocław-Warszawa: Zakład Narodowy im. Ossolińskich.

Małgorzata Durbas, professor at the Institute of History, Jan Dlugosz University in Częstochowa, specialises in the modern history of Poland and the history of relationships between Poland and French and Lorraine. Her research touches upon the broadly understood cultural and social space of the Duchy of Lorraine and Bar at the time of integration with the House of Bourbon during the reign of King Stanisław Leszczyński. Her academic output includes analyses of many topics concerning the modernisation processes as well as the institutionalisation of academic research, artistic patronage and charity activity. Her current main area of research is the image of the functioning of academic life in the 18th century. 